\title{
Formalisasi Syariat Islam Di Tasikmalaya
}

\author{
Anang Zubaidy \\ PSHK FH UII JI. Lawu No.1 Yogyakarta \\ e-mail:anang_bism@yahoo.com
}

\begin{abstract}
Together with the occurrence of democracy in Indonesia through reformation in 1998, the practice on state administration is in dynamic way. One of the dynamics is the existence of the regional autonomy whose implementation triggered a wide interpretation among society. One of the pros and cons around regional autonomy is the existence of shariah regional regulation in some places in Indonesia; one of them is in Tasikmalaya regency. Those who agree on this regulation based themselves on regional autonomy. Meanwhile, the ones who against the regulation have argument on the basis that religion business is on the hand of a central authority which is not given as a part of the autonomy.
\end{abstract}

Abstract

Keywords: Shariah Legislation, Local Ordinance

\section{Pendahuluan}

Umat beragama seperti pula halnya umat Islam, mempunyai tatanan sistem hukum agama sebagai ketetapan Tuhan yang melandasi setiap perilaku dan tindakan mereka. Dalam Islam, ketetapan Tuhan yang berupa tuntunan beragama ini disebut dengan istilah Syariat Islam. Setiap agama mempunyai nama-nama peristilahan sendiri sebagai sebutan bagi tatanan sistem hukum agama tersebut. Islam sebagai agama yang merupakan satu kesatuan sistem kehidupan, memiliki tiga kerangka dasar utama, yaitu Akidah, Syariat dan Akhlak. Ketiga hal tersebut secara simultan harus dipegang oleh setiap muslim.

Sebagaimana halnya yang berlaku di dalam agama-agama lain, Syariat dalam Islam mempunyai kedudukan yang urgen sebagai pengarah sekaligus pembimbing ummat Islam dalam mengimplementasikan kehambaannya kepada Sang Khalik, Allah SWT. Oleh karena itu, penerapan Syariat Islam dalam setiap perilaku kehidupan ummat Islam menjadi suat hal yang qath'iy (mutlak), tidak boleh tidak. 
Dalam konteksnya sebagai bangsa yang berpenduduk mayoritas muslim, Indonesia dalam peta dunia Islam merupakan fenomena keislaman tersendiri yang kadang berbeda dengan ummat Islam lain pada belahan dunia lain, baik pada aspek kenegaraan maupun kondisi masyarakatnya. Bukti nyata ummat Islam di Indonesia "lain daripada yang lain" adalah selain Indonesia berpenduduk muslim terbesar di dunia, juga karena di tengah-tengah kehidupan bangsa yang berpenduduk mayoritas muslim ini, segala persoalan kenegaraan, kebangsaan, dan kemasyarakatan tidak didasarkan kepada suatu paham keagamaan yakni Islam. Justru yang menjadi pandangan hidup (way of life) dan ideologi negara adalah Pancasila, sejumlah nilai dasar yang digali dari bumi Indonesia sendiri yang pada tingkat tertentu bisa menjadi "titik temu" (kalimat sawa'). ${ }^{1}$

Kenyataan inilah yang memunculkan, beberapa pandangan baik dari kelompok non Islam maupun ummat Islam sendiri. Pandangan yang menginginkan dengan pemberlakuan Syariat Islam menyatakan bahwa Pancasila sebagai dasar negara tidak cukup menjamin pelaksanaan syariat agama dan oleh karena itu mereka menginginkan pemberlakuan Syariat Islam melalui wujud formalisasi Syariat Islam.

Keinginan kelompok yang menginginkan formalisasi syariat bukan tanpa tanding. Keinginan tersebut memunculkan perlawanan dari kelompok yang tidak menginginkan adanya formalisasi syariat agama apapun di Indonesia. Konflik akhirnya mengerucut pada dua kutub yang saling berseberangan yakni antara yang menginginkan adanya formalisasi pemberlakuan syariat dengan yang tidak setuju dengan bentuk formalisasi.

Tuntutan formalisasi Syariat Islam yang muncul beberapa tahun belakangan ini bukan merupakan fenomena baru dalam perjalanan sejarah bangsa Indonesia. Usaha (formalisasi) ini sudah dimulai sejak perumusan dasar negara dalam Badan Penyelidik Usaha Persiapan Kemerdekaan (BPUPKI). Saat itu, kelompok Nasionalis Islami yang menjadi anggota dalam Dokuritsu Zyunbi Tyoosakai (BPUPKI), sebuah lembaga yang dibentuk pada tanggal 25 April 1945 oleh penjajah Jepang, harus berjuang keras menghadapi kelompok lain yang diwakili oleh kelompok Nasionalis Sekuler ${ }^{2}$ yang menginginkan tidak ditampilkannya

${ }^{1}$ Marzuki Wahid dan Rumadi, Figh Madzhab Negara; Kritik atas Politik Hukum Islam di Indonesia, LKiS, Yogyakarta, 2001, hlm. 1.

${ }^{2}$ Sebutan Nasionalis Islami dan Nasionalis Sekuler hanyalah suatu simbolisasi 
simbol agama tertentu ke dalam rumusan dasar negara. Kelompok Nasionalis Sekuler beranggapan bahwa untuk menghindari perpecahan serta akibat-akibat destruktif lainnya yang akan menggiring kepada disintegrasi bangsa, maka sebaiknya tidak ada simbol-simbol agama tertentu yang tertuang di dalam dasar negara.

Titik temu yang diharapkan dari perdebatan-perdebatan dalam BPUPKI tidak dapat dicapai. Upaya kompromi akhirnya dilakukan dengan melepas 7 (tujuh) kata dalam Piagam Jakarta dari dasar negara. Tujuh kata kontroversial dalam Piagam Jakarta 22 Juni 1945 tersebut adalah; "Kewajiban menjalankan syariat Islam bagi pemelukpemeluknya".

Kegagalan ummat Islam untuk mewujudkan formalisasi pemberlakuan Syariat Islam tidak menjadikan perjuangan ini surut dan patah arang. Upaya ini terus berlanjut dalam sejarah panjang bangsa Indonesia hingga di era reformasi sekarang ini. Tuntutan demi tuntutan datang silih berganti dari berbagai elemen ummat Islam dengan dasar keyakinan bahwa hanya Syariat Islam yang mampu menjadi alternatif solusi untuk keluar dari krisi multi-dimensi ini.

Ketika hiruk pikuk perdebatan mengenai bentuk pemberlakuan Syariat Islam di Indonesia antara formalisasi dan aktualisasi substansi belum usai, beberapa daerah bahkan telah nyata-nyata mendeklarasikan penerapan Syariat Islam di daerahnya masing-masing. Tuntutan pemberlakuan Syariat Islam di daerah-daerah ini semakin marak sejak tuntutan pemberlakuan Syariat Islam ditolak parlemen melalui proses amandemen Undang-Undang Dasar 1945 pada tahun 2002 silam.

Tuntutan ini dimulai dari Aceh dengan pemberlakuan Syariat Islam di Propinsi paling ujung utara wilayah Indonesia ini. Keingingan rakyat Aceh untuk memformalkan Syariat Islam di daerahnya direspon positif oleh Pemerintah Pusat dengan membentuk aturan formal. Melalui UndangUndang Nomor 44 tahun 1999 tentang Otonomi Khusus NAD, Propinsi Nanggroe Aceh Darussalam terhitung mulai tanggal 1 Muharram 1423 H (15 Maret 2002) secara resmi telah memberlakukan Syariat Islam di bumi Serambi Mekkah.

Setelah Propinsi Aceh memberlakukan Syariat Islam dengan landasan yuridis Undang Undang Nomor 44 Tahun 1999 tersebut, beberapa daerah

untuk membedakan dua kelompok yang saling bertentangan antara tuntutan penegakan Syariat Islam di Indonesia atau tanpa penegakan Syariat agama tertentu dibumi Nusantara. 
lain kemudian berusaha menuntut pemberlakuan Syariat Islam di daerahnya masing-masing sebagaimana yang telah terjadi pada saudarasaudaranya di Aceh. Beberapa daerah tersebut diantaranya Kabupaten Pamekasan yang sedang menerapkan program "Gerbang Salam". Penerapan program "Gerbang Salam" di salah satu kabupaten di Pulau Madura ini dimaksudkan untuk membangun masyarakat yang taat pada aturan-aturan hukum dengan spirit agama Islam.

Lain Pamekasan lain pula yang terjadi di 3 (tiga) Kabupaten di Propinsi Jawa Barat. Tercatat, Kabupaten Garut, Cianjur dan Tasikmalaya juga telah menyatakan diri sebagai daerah yang melakukan pemberlakuan Syariat Islam. Pemerintah Kabupaten Garut sempat memunculkan “Deklarasi Penegakan Syariat Islam" pada tanggal 1 Muharram $1423 \mathrm{H}$ dengan segala pro dan kontranya, yang berumur kurang lebih hanya sekitar 3 (tiga) bulan. Di Tasikmalaya, melalui Peraturan Daerah tentang Rencana Strategis Kabupaten Tasikmalaya, telah dengan tegas mengangkat visi Religius/Islami sebagai starting point menuju pemberlakuan Syariat Islam di daerah yang dikenal dengan sebutan "kota santri" ini.

Jika pemberlakuan Syariat Islam yang dilaksanakan di Propinsi Nanggroe Aceh Darussalam didasarkan pada Undang-Undang Nanggroe Aceh Darussalam Nomor 14 tahun 1999, maka apakah yang menjadi dasar bagi pelaksanaan pemberlakuan Syariat Islam di daerah-daerah lain tersebut. Jika yang terjadi di berbagai daerah lain didasarkan pada Peraturan Daerah setempat jelas akan menimbulkan persoalan baru ketika harus dihadapkan dengan Undang-Undang Nomor 22 Tahun 1999 tentang Pemerintahan Daerah sebagaimana yang telah diubah dengan Undang-undang Nomor 32 Tahun 2004 tentang Pemerintahan Daerah. Kedua undang-nudang yang mengatur otonomi daerah setelah reformasi tersebut secara tegas menyatakan bahwa urusan agama bukan merupakan bidang yang diotonomikan ke daerah. Mengambil salah satu contoh penerapan syariat di berbagai daerah, tulisan ini akan mengangkat penerapan syariat Islam yang pernah dan hingga saat ini masih berlangsung di Kabupaten Tasikmalaya.

Sebagai gambaran awal disini akan disebutkan secara dekriptif kondisi obyektif kabupaten Tasikmalaya. Tasikmalaya adalah sebuah kabupaten yang terletak di ujung timur Jawa Barat atau biasa disebut sebagai wilayah Priangan Timur. Kondisi demografis dan kultural masyarakat Tasikmalaya sebenarnya telah terkesan Islami, setidaknya 
tampak dari berbagai simbol keagamaan yang begitu kuat dan tercermin dari kehidupan lahiriahnya.

Secara statistik, Tasikmalaya mempunyai penduduk mayoritas muslim. Disamping sekitar 99,6\% penduduknya beragama Islam, telah lama kota ini berpredikat sebagai "Kota Santri"3 karena memiliki kurang lebih 700 buah pesantren yang tersebar di berbagai wilayah baik di kota maupun pedesaan yang mendidik ratusan ribu santri. Sebutan "Kota Santri" memberikan isyarat yang kuat dan pekat dengan muatan keislaman.

\section{Syariat Islam di Tasikmalaya}

Tasikmalaya adalah sebuah kabupaten yang terletak wilayah timur Propinsi Jawa Barat. Wilayah ini biasa disebut wilayah Priangan Timur. Kabupaten Tasikmalaya secara keseluruhan memiliki luas 2.563,35 Kilometer persegi ${ }^{4}$. Mata pencaharian utama dari masyarakat Kabupaten Tasikmalaya adalah tani yang mencapai $41 \%$ dari total penduduk. Sebuah kondisi umum penduduk Indonesia yang berciri agraris. ${ }^{5}$ Seperti kebanyakan masyarakat agraris di daerah lain di Indonesia, penduduk Kabupaten Tasikmalaya cenderung agamis meskipun kesan mistik dan paham dinamisme animisme masih mewarnai pola kehidupan dan tradisi mereka.

Kehidupan beragama masyarakat Kabupaten Tasikmalaya (khususnya Islam) telah lama dimulai berkat kerja keras para Kiai yang mengembangkan ajaran agama Islam di Tasikmalaya. Usaha penyebaran Islam ini menggunakan media-media tradisi lokal yang telah lama ada sebelum Islam masuk kesana seperti wayang, musik tradisional dan sebagainya. Selain itu, masuknya agama Islam di Tasikmalaya juga melalui jalur perdagangan dan perkawinan.

Kondisi kehidupan beragama masyarakat Kabupaten Tasikmalaya (khususnya) muslim dengan nuansa dan nafas Islami nampak mewarnai segenap perikehidupannya. Tradisi turun-temurun ${ }^{6}$ yang telah mengakar

\footnotetext{
${ }^{3}$ http:/ / www.klikpriangan.com/102003/tajuk.htm

${ }^{4}$ Lampiran Perda Kabupaten Tasikmalaya Nomor 13 Tahun 2003 tentang Perubahan Kedua Peraturan Daerah Kabupaten Tasikmalaya Nomor 03 Tahun 2001 tentang Rencana Strategis Kabupaten Tasikmalaya Tahun 2001-2005.

${ }^{5}$ Ibid.

${ }^{6}$ Tradisi ini diyakin banyak dipengaruhi oleh ajaran-ajaran agama Islam. Ajaran atau nilai-nilai agama Islam ini telah melakukan akulturasi dengan kebudayaan setempat dan menghasilkan sintesa kebudayaan yang unik tetapi tidak bertentangan dengan nilai dasar dari ajaran agama Islam itu sendiri.
} 
dalam kehidupan masyarakatnya senantiasa dipertahankan oleh masyarakat setempat. Bahkan pemerintah daerah Kabupaten Tasikmalaya secara proaktif telah memberikan tempat yang istimewa dengan menjadikannya sebagai obyek kunjungan wisata. Bukti dari keingingan tersebut adalah apa yang bisa dilihat di Lokasi Khas Wisata Budaya Kampung Naga yang secara resmi dinobatkan sebagi salah satu lokasi kunjungan wisata di Kabupaten Tasikmalaya.

Kampung Naga merupakan perkampungan tradisional yang memiliki luas areal sekitar 15 (lima belas) hektar. Lokasi Khas Wisata Budaya Kampung Naga terletak pada ruas jalan yang menghubungkan Kabupaten Tasikmalaya dengan Kabupaten Garut. ${ }^{7}$ Beberapa ritual yang kental nafas Islamnya yang secara rutin dilaksanakan di Lokasi Khas Wisata Budaya Kampung Naga berupa upacara-upacara "sasihan" (bulanan) yang meliputi: 'Idul Adha yang dilaksanakan tepat pada tanggal 10 (sepuluh) Dzul Hijjah, Mendak Taun pada 28 (dua puluh delapan) Muharram, Maulid Nabi pada setiap tanggal 12 (dua belas) Rabi'ul Awwal, Isro' Mi'roj pada tanggal 27 (dua puluh tujuh) Rajab, Nisfu Sya'ban setiap tanggal 1 (satu) Ruwah (Sya'ban), 'Idul Fitri pada tanggal 1 (satu) Syawal dan upacara Pedaran (upacara yang dilaksanakan setiap delapan bulan sekali) yang jatuh pada bulan Mulud. ${ }^{8}$

Selain Kampung Naga, Pemerintah Daerah juga menetapkan daerah tujuan wisata lain dengan ciri dan kekhasan yang tidak berbeda dengan Kampung Naga sebagai salah satu daerah kunjungan wisata. Pemilihan daerah ini sebagai daerah kunjungan wisata dimaksudkan untuk memperlihatkan betapa tradisi Islam telah kuat mengakar di Tasikmalaya. Wisata tersebut terkenal dengan nama Wisata Ziarah Pamijahan yang terletak di Desa Pamijahan, kecamatan Bantarkalong, sekitar 65 (enam puluh lima) kilometer dari Kota Tasikmalaya ke arah selatan. ${ }^{9}$ Lokasi khas wisata ini kental dengan acara-acara ritual agama Islam, terutama pada hari-hari besar Islam yang merupakan puncak ramainya pengunjung ziarah ke Pamijahan.

Kehidupan beragama masyarakat Kabupaten Tasikmalaya (khususnya Islam) telah lama dimulai berkat kerja keras para Kiai yang

\footnotetext{
${ }^{7}$ Lampiran Perda Kabupaten Tasikmalaya Nomor 13 Tahun 2003 tentang Perubahan Kedua Peraturan Daerah Kabupaten Tasikmalaya Nomor 03 Tahun 2001 tentang Rencana Strategis Kabupaten Tasikmalaya Tahun 2001-2005.

${ }^{8}$ Ibid.

${ }^{9}$ Ibid., hlm. II-22.
} 
mengembangkan ajaran agama Islam di Tasikmalaya. Usaha penyebaran Islam ini menggunakan media-media tradisi lokal yang telah lama ada sebelum Islam masuk kesana seperti wayang, musik tradisional dan sebagainya. Selain itu, masuknya agama Islam di Tasikmalaya juga melalui jalur perdagangan dan perkawinan.

Gerakan formalisasi penerapan syariat Islam di Tasikmalaya ditandai dengan ditetapkannya Pemerintah Daerah Tasikmalaya telah mengeluarkan Perda Nomor 1 Tahun 2000 yang melarang pelacuran dan kegiatan-kegiatan kemaksiatan. Gerakan ini kemudian mengkristal dengan ditetapkannya Peraturan Daerah (Perda) Nomor 3 Tahun 2001 tentang Rencana Strategis (Renstra) Kabupaten Tasikmalaya Tahun 2001-2005. Dalam Perda tentang Renstra Kabupaten Tasikmalaya itulah visi Religius/ Islami dijadikan rumusan sebagai suatu cita-cita yang akan dicapai oleh masyarakat Kabupaten Tasikmalaya.

Perda tentang pelacuran yang menimbulkan kontroversi tersebut memuat beberapa hal yang patut mendapatkan catatan penting yakni: 1 . Dalam suratnya Nomor 57/MUI-TSM/XII/1999 tertanggal 22 Desember 1999, Majelis Ulama Indonesia Kabupaten Tasikmalaya telah mengeluarkan fatwa yang dikhususkan berupa bahan-bahan penyusunan Perda Prostitusi. Dalam fatwa itu disebutkan definisi pelacuran dengan pengistilahan zina. Substansi zina ini kemudian dijadikan sebagai masukan dalam menentukan definisi pelacuran dalam Perda. Definisi pelacuran yang dimaksud dalam Perda tersebut adalah: "perbuatan yang dilakukan oleh siapapun dengan sengaja dan bertujuan mencari kepuasan syahwat dan atau bersetubuh atau berzina di luar ikatan pernikahan yang sah dengan atau tanpa menerima imbalan baik berupa uang maupun dalam bentuk lain"; ${ }^{10}$ 2. Dalam Perda tentang Pemberantasan Pelacuran tersebut tidak dibedakan antara Zina Muhshon dengan Zina Ghairu Muhshon sebagaimana dalam syariat Islam yang memberikan penegasan masalah tersebut; 3. Dalam Perda tersebut juga tidak disebutkan sanksi pelanggaran bagi pelaku perzinahan yang berupa rajam atau jild sebagaimana ketentuan Islam mengajarkan hal tersebut.

Visi syariat Islam yang dicoba dicanangkan penerapannya di Kabupaten Tasikmalaya, tidak terlepas dari nilai-nilai daerah setempat

${ }^{10}$ Peraturan Daerah Kabupaten Tasikmalaya Nomor 28 Tahun 2000 tentang Perubahan Pertama Peraturan Daerah Kabupaten Tasikmalaya Nomor 01 Tahun 2000 tentang Pemberantasan Pelacuran pasal 1 huruf g. Bandingkan dengan definisi zina dalam versi Kitab Undang Undang Hukum Pidana (KUHP). 
(cultrure core) yang mayoritas beragama Islam, tradisi-tradisi yang kental dengan nuansa dan nafas Islami, kondisi impian dan cita-cita masyarakat Tasikmalaya yang mencita-citakan kehidupan yang lebih baik sebagai salah satu harapan menuju masyarakat madani.

Makna "religius" atau keberagamaan sesungguhnya secara sederhana merupakan pencerminan ketaqwaan terhadap Tuhan Yang Maha Esa dalam kehidupan sehari-hari sesuai dengan agama yang dianutnya. ${ }^{11}$ Berdasarkan penjelasan mengenai visi religius Kabupaten Tasikmalaya ini maka makna religius mencakup seluruh umat pemeluk agama. Sedangkan kata "Islami" merupakan penegasan akan kondisi masyarakat Kabupaten Tasikmalaya yang 99,9\% beragama Islam. ${ }^{12}$

Sebagaimana yang terjadi di daerah-daerah lain yang memunculkan sikap setuju dan tidak setuju dengan pemberlakuan syariat Islam, demikian pula halnya yang terjadi di Kabupaten Tasikmalaya ketika visi religius/Islami ini digulirkan. Salah satu alasan kelompok yang tidak setuju adalah bahwa masyarakat yang mayoritas beragama Islam bukan menjadi satu-satunya modal untuk dapat memuluskan keingingan formalisasi syariat Islam. Kenyataan sebagai pemeluk mayoritas juga tidak boleh dijadikan alat untuk menafikkan keberadaan ummat yang lain yang mempunyai hak yang sama sebagai warga negara.

Tanggapan tidak setuju ini banyak berasal dari kalangan ummat Islam sendiri. Berbagai cara dilakukan dari mulai dialog hingga aksi demonstrasi dilakukan oleh kelompok yang menentang formalisasi syariat dengan berbagai alasan. Tentangan ini memunculkan usulan perubahan renstra yang mengusung visi Islam tersebut. Wacana itu datang dari banyak kelompok masyarakat terutama dari berbagai Lembaga Swadaya Masyarakat (LSM) di Tasikmalaya. ${ }^{13}$ Berbagai upaya dilakukan untuk menolaknya dari mulai sikap kritis dalam bentuk dialog hingga penolakan dalam bentuk aksi massa.

${ }^{11}$ Lampiran Peraturan Daerah Kabupaten Tasikmalaya Nomor 13 Tahun 2003 tentang Perubahan Kedua Peraturan Daerah Kabupaten Tasikmalaya Nomor 03 Tahun 2001 tentang Rencana Strategis Kabupaten Tasikmalaya Tahun 2001-2005. hlm. IV-2

${ }^{12}$ Ibid.

${ }^{13}$ Kelompok Lembaga Swadaya Masyarakat yang menentang formalisasi syariat ini diantaranya adalah LKaHAM. LKaHAM adalah LSM yang beranggotakan mahasiswa dari berbagai perguruan tinggi di Tasikmalaya. Uniknya, para anggota LSM ini kebanyakan alumnus Pondok Pesantren-Pondok Pesantren yang ada di Tasikmalaya. 
Sedangkan di pihak lain yang setuju dengan formalisasi telah lebih dahulu melakukan upaya konkrit dengan melakukan sweeping ke tempattempat yang dianggap sebagai tempat maksiat. Selain sweeping tindakan yang dilakukan juga berupa larangan seorang gadis keluar rumah pada malam hari yang tidak ditemani oleh muhrimnya. Tindakan atas nama hukum sendiri ini dapat digolongkan sebagai perbuatan main hakim sendiri (eigenrichting) yang jelas tidak dapat dibenarkan oleh sistem hukum negara manapun.

Suasana semakin mengkristalnya kepentingan dua kelompok masyarakat yang pro dan kontra dengan Perda Renstra Nomor 3 Tahun 2001 memaksa Pemerintah Daerah dan DPRD Kabupaten Tasikmalaya untuk melakukan perubahan terhadap Perda Nomor 3 Tahun 2001 tersebut. Pada tanggal 9 Oktober 2003 Perda Nomor 13 Tahun 2003 tentang Perubahan Kedua Perda Nomor 03 Tahun 2001 tentang Rencana Strategis Kabupaten Tasikmalaya Tahun 2001-2005 ditetapkan. Kendati telah dilakukan perubahan, visi religius/Islami yang menjadi akar permasalahan masih tetap dipertahankan. Hanya saja, misi dan strategi kebijakan yang sebelumnya memuat "Penyiapan Peraturan DaerahPeraturan Daerah Islami"14 dihapus.

Ditinjau dari makna substansi dari perubahan Perda Renstra di atas maka dapat ditarik beberapa hal: 1. Semangat Pemerintah Daerah Kabupaten beserta DPRD Kabupaten Tasikamalaya untuk menciptakan suasana yang Religius/Islami melalui bentuk-bentuk aturan formal di daerah terlihat mengendur. Perubahan tersebut telah memunculkan pergeseran paradigma (paradigma shifting) dalam memahami makna implementasi syariat Islam. Jika sebelumnya pemaknaan implementasi syariat Islam di Kabupaten Tasikmalaya dimaknai sebagai upaya formalisasi yang menonjolkan simbol-simbol, maka dalam perubahan Renstra hal itu tidak terjadi. Yang terjadi adalah upaya penggalian maknamakna substantif dari ajaran Islam dalam syariat untuk diimplementasikan kedalam berbagai macam aturan kebijakan daerah; 2 . Melunaknya sikap Pemerintah Daerah dan DPRD Kabupaten Tasikmalaya dengan memberikan warna pemahaman yang lain dari visi religius/Islami. Jika sebelumnya visi religius/Islami dipahami sebagai implementasi syariat Islam dengan (mengabaikan) komunitas-komunitas agama lain, maka

${ }^{14}$ BAB IV "Strategi Pembangunan", Point C "Strategi Pembangunan Keagamaan, Sosial dan Budaya". Sub A Point ke-6 Peraturan Daerah Nomor 3 Tahun 2001 tentang Rencana Strategis Kabupaten Tasikmalaya tahun 2001-2005. 
dalam perubahan Perda ini visi religius diberi makna sebagai manifestasi ketaqwaan semua pemeluk agama bukan salah satu agama tertentu saja.

Dengan dirubahnya Peraturan Daerah Nomor 3 Tahun 2001 tentang Rencana Strategis Kabupaten Tasikmalaya tahun 2001-2005 dengan Peraturan Daerah Nomor 13 Tahun 2003 tentang Perubahan Peraturan Daerah Nomor 3 Tahun 2001 tentang Rencana Strategis Kabupaten Tasikmalaya tahun 2001-2005, maka arah kebijakan Pemerintah Kabupaten Tasikmalaya, dengan demikian, juga mengalami perubahan strategi. Perubahan strategi yang paling ekstrim adalah dengan dibatalkannya niat untuk menerapkan implementasi syariat Islam ke dalam Peraturan Daerah.

Perubahan strategi ini membawa pengaruh terhadap pola kebijakan Pemerintah Daerah. Usaha untuk menjadikan Islam sebagai pedoman hidup di Kabupaten Tasikmalaya masih tetap dilakukan kendati tidak menyangkut hal-hal yang prisipal, seperti: 1 . Adanya ajakan dari Bupati Tasikmalaya untuk melaksanakan sholat Dzuhur dan shalat Jum'ah kepada seluruh Pegawai Negri di lingkungan Sekretariat Daerah melalui suratnya nomor 45111/1334/Sos tanggal 3 Juni 2002; 2. Adanya anjuran untuk mengenakan busana muslim-muslimah bagi seluruh PNS khusus pada hari Jum'at. Anjuran ini kental dengan nuansa simbolistik dari ajaran Islam itu sendiri; 3. Diaktifkannya MUI Kabupaten Tasikmalaya dalam memberikan kontribusi pemikiran mengenai hal-hal yang berkaitan dengan masalah-masalah ummat. Kerjasama ini juga berupa pemberian penyuluhan dan pelatihan-pelatihan keagamaan yang dilaksanakan antara Pemerintah Daerah dengan MUI. Sebagian fatwa MUI justru dijadikan rujukan dalam pembuatan peraturan perundang-undangan tingkat Daerah 4. Adanya kewajiban bagi para calon siswa siswi SD dan SLTP untuk lulus Taman Pendidikan Al Qur'an (TPQ) sebagai prasyarat untuk masuk SD dan SLTP. Prasyarat ini semata-mata untuk mensosialisasikan Al Qur'an semenjak dini.

\section{Formalisasi Syariat: Aspirasi Rakyat atau Kepentingan Elit Politik?}

Gerakan penerapan syariat Islam di Propinsi Jawa Barat berbeda dengan gerakan penerapan syariat Islam di Propinsi Nanggroe Aceh Darussalam dan Sulawesi Selatan. Gerakan syariat Islam pada kedua propinsi tersebut menggema di pusat Propinsi sedangkan gerakan penerapan syariat Islam di Jawa Barat justru berlangsung di luar pusat 
Propinsi (Bandung). Haedar Nashir menengarai bahwa gerakan penerapan syariat Islam di Jawa Barat yang tidak dimulai dan menggema di Bandung karena pluralitas masyarakat dengan dinamika sosial-politik yang lebih beragam, sehingga tidak meluas dan mengerucut menjadi gumpalan gerakan sebagaimana yang terjadi di Aceh dan Sulawesi Selatan. ${ }^{15}$ Namun demikin, di antara ketiganya (Aceh, Sulawesi Selatan dan sebagian wilayah Jawa Barat) memiliki kesamaan yaitu ummat Islam yang mayoritas dan dikenal secara nominal sebagai penganut Islam taat dan bahkan fanatik.

Fanatisme terhadap Islam inilah yang mempengaruhi sebagian besar masyarakat Kabupaten Tasikmalaya. Momentum reformasi kemudian dijadikan sebagai jalan terang menuju penerapan syariat Islam. Gerakan ini dimulai sejak bulan Desember 2000 yang pada awalnya dilakukan oleh kelompok-kelompok Islam dalam masyarakat termasuk para santri dan organisasi-organisasi Islam setempat yang kemudian tergabung dalam Forum Bersama Pemuda Islam (FBPI), kemudian dikembangkan melalui jalur pemerintahan daerah. ${ }^{16}$

Pengembangan melalui jalur Pemerintah Daerah mendapatkan peluang yang besar menyusul dimenangkannya kontestasi Pemilu 1999 oleh PPP. ${ }^{17}$ Berdasarkan hasil Pemilu pada tahun 1999 yang lalu, PPP menempati urutan pertama dan bersaing ketat dengan Partai Golkar dan PDI-P yang berada pada posisi kedua dan ketiga. Sementara urutan keempat dan seterusnya adalah PKB, PAN, PBB, PK dan PKP. ${ }^{18}$

Komposisi keanggotaan DPRD Kabupaten Tasikmalaya tersusun berdasarkan perolehan suara yang terdiri dari: ${ }^{19}$ PPP sebanyak 11 (sebelas) orang, Partai Golkar sebanyak 9 (sembilan) orang, PDI-P sebanyak 8 (delapan) orang, PKB sebanyak 5 (lima) orang, PAN sebanyak 3 (tiga) orang, PBB sebanyak 2 (dua) orang, PK 1 dan PKP masing-masing mendapatkan bagian 1 (satu) kursi. Sedangkan anggota DPRD Kabupaten Tasikmalaya berdasarkan pengangkatan dari unsur TNI-POLRI adalah

${ }^{15}$ Haedar Nashir, Gerakan Islam Syariat: Reproduksi Salafiyah Ideologis di Indonesia, Cetakan I, Pusat Studi Agama dan Peradaban (PSAP) Muhammadiyah, Jakarta, 2007, hlm. 354 .

${ }^{16}$ Ibid., hlm. 372.

${ }^{17}$ Partai ini berasaskan Islam dan selalu membawa isu-isu penerapan syariat Islam sebagai bagian dari kampanye politiknya.

${ }^{18}$ Dokumen Dinas Kesatuan Bangsa dan Hubungan Masyarakat (KESBANG DAN HUMAS) Kabupaten Tasikmalaya.

${ }^{19}$ Ibid. 
sebanyak 5 orang. Total keseluruhan dari anggota DPRD Kabupaten Tasikmalaya pada Pemilu tahun 1999 adalah 45 (empat puluh lima) orang.

Berdasarkan hasil pemilu tersebut, jika dikualifikasi komposisi keanggotaan DPRD berdasarkan stigma partai agama (Islam) dengan partai Nasionalis terlihat bahwa partai yang berbasis massa dan berideologi Islam terdiri dari PPP, PKB, PAN, PBB dan PK. Sedangkan untuk partai yang berbasis massa nasionalis terdapat PDI-P, Partai Golkar dan PKP ditambah lagi dari beberapa anggota DPRD yang mewakili unsur TNIPOLRI.

Golongan pertama (Islam) meskipun hanya PPP, PBB dan PK yang menggunakan Islam sebagai ideologi partai, partai-partai lain seperti PKB dan PAN masih sangat relevan untuk dimasukkan dalam golongan ini meski kedua partai ini memilih Pancasila sebagai ideologi partai. Hal ini tidak lain dikarenakan basis pemilih kedua partai tersebut adalah mayoritas (bahkan bisa dikatakan seluruh pemilihnya) adalah muslim.

PKB merupakan partai yang dibentuk dan dipimpin oleh para Kiai yang mempunyai basis massa NU yang merupakan kelompok mayoritas terbesar di Tasikmalaya sedangkan PAN adalah partai yang di dalamnya terdapat mayoritas komunitas organisasi Persyarikatan Muhammadiyah yang tentunya basis massanya jelas ummat Islam. Kenyataan ini tidak dapat dipungkiri akan mempersempit ideologi kedua partai ini karena dalih perjuangan konstituen yang mayoritas muslim.

Sementara Partai Demokrasi Indonesia Perjuangan (PDI-P) selain berideologi Pancasila juga karena mayoritas pemilihnya adalah kelompok nasionalis (sekuler). Kalaupun ada kelompok Islam yang mendukung Partai Demokrasi Indonesia Perjuangan (PDI-P) ini, hanya mewakili kelompok Islam abangan. Partai Golkar selain diisi oleh para birokrat juga karena ideologinya yang menganut Pancasila. Terakhir, Partai Persatuan dan Kesatuan (PKP), partai yang didominasi oleh para purnawirawan TNI serta eks kader Golkar ini juga berideologi Pancasila.

Dari perolehan kursi di DPRD Kabupaten Tasikmalaya, partai-partai dengan basis massa Islam memperoleh kursi lebih dari $50 \%$ dari keseluruhan anggota dewan dengan menempatkan 22 (dua puluh dua) orang sedangkan partai-partai nasionalis hanya mendapatkan 18 kursi. Sisa 5 (lima) kursi lainnya yang terdiri dari utusan dari TNI/POLRI bersifat netral.

Dalam pelaksanaan demokrasi di negara manapun di dunia, sikap atau pilihan mayoritas akan menjadi keputusan bersama yang harus 
disepakati. Partai politik pemenang Pemilu, juga dengan sendirinya mempunyai hak untuk mengambil posisi puncak kekuasaan. Hal ini juga berlaku di DPRD Kabupaten Tasikmalaya. Partai yang memperoleh suara terbanyak yaitu PPP dengan didukung oleh partai-partai yang lain dapat mendudukkan kadernya sebagai Bupati.

Kemenangan PPP yang berideologi Islam dan mengusung visi penegakan syariat Islam di Indonesia (meskipun tidak mutlak) serta terpilihnya Bupati dari PPP sangat berpengaruh dalam konstalasi politik di Kabupaten Tasikmalaya. Proses pengambilan kebijakan di tingkat DPRD dalam penetapan Peraturan Daerah jelas dipengaruhi oleh kemenangan PPP serta komposisi kursi di DPRD.

Pembentukan Peraturan Daerah (Perda) Nomor 3 Tahun 2001 tersebut didasarkan pada landasan yuridis berupa peraturan perundangundangan yang berlaku sebagai hukum positif di Indonesia. Dari sekian aturan hukum yang dijadikan sebagai landasan yuridis pembentukan Perda tentang Renstra, tampak tidak ada satupun landasan-landasan hukum yang berasal dari sumber hukum Islam. Sumber hukum Islam yang paling utama adalah Al Qur'an dan As Sunah Rasulullah SAW. Jika benar maksud pembuatan Peraturan Daerah ini merupakan manifestasi dari ajaran Islam untuk memformalkan Syari'at, maka merupakan suatu kejanggalan jika sumber utama hukum Islam sendiri tidak dijadikan sebagai landasan yuridis pembentukan Peraturan Daerah.

\section{Otonomi Bukan Mendesentralisasikan Urusan Agama}

Salah satu kegagalan pemerintahan Orde Baru adalah ketidakmampuannya untuk mewujudkan kesejahteraan yang merata dari pusat hingga daerah. Pelaksanaan pemerintahan yang sangat sentralistik telah memunculkan satu kekuatan yang terpusat dan hegemonik. Rakyat di daerah dipaksa tunduk kepada satu kebijakan yang sentralistik tanpa punya kekuatan untuk menolaknya.

Melalui ide reformasi pemerintahan, muncul tuntutan untuk mengembalikan kedaulatan rakyat di daerah berupa partisipasi rakyat di daerah dalam menetapkan dan menentukan sendiri nasib daerahnya. Pola pemerintahan sentralistik (bahkan cenderung paternalistik) yang telah diterapkan semenjak berdirinya Negara Indonesia terbukti telah membunuh demokrasi di daerah serta menutup peran aktif rakyat di daerah dalam menentukan nasib daerahnya sendiri. 
Kebijakan otonomi daerah yang muncul sebagai tuntutan daerah untuk berperan dalam menentukan kehidupan daerahnya sendiri, tidak bisa dipandang sebagai agenda terpisah dari agenda besar tuntutan demokratisasi di Indonesia. Konsekuensi logis dari cara pandang yang demikian harus diposisikan sebagai instrumen desentralisasi-demokratisasi. Otonomi daerah dapat diartikan sebagai otonomi 'rakyat daerah', bukan otonomi pemerintah daerah. Oleh sebab itu, otonomi merupakan hak rakyat di daerah yang semestinya menyatu dalam setiap agenda pembangunan di daerah. Maka dari itu, adalah tidak mengherankan jika pelaksanaan otonomi daerah senantiasa diikuti oleh tuntutan rakyat daerah dalam bentuk artikulasi keinginan rakyat tentang banyak hal.

Sebelum lahirnya Undang-Undang Nomor 22 Tahun 1999 tentang Pemerintahan Daerah, hubungan sentralistik merupakan sejarah buruk bagi pelaksanaan pemerintahan, sehingga Tap. MPR Nomor X/MPR/ 1998, tentang Pokok-Pokok Reformasi Pembangunan telah memberikan rekomendasi untuk mengakhiri sentralistiknya kekuasaan. Permasalahan juga tidak berhenti manakala Undang-undang Nomor 22 Tahun 1999 diberlakukan.

Setidaknya terdapat 10 (sepuluh) permasalahan yang menggelayuti implementasi Undang-undang Nomor 22 Tahun 1999 sebagaimana dirangkum oleh Abdul Gaffar Karim..$^{20}$ Pertama, berkaitan dengan hubungan kekuasaan antara Pusat dan Daerah. Implementasi otonomi belum secara nyata menunjukkan locus kekuasaan apakah di tingkat daerah ataukah di tingkat pusat. Kedua, selain permasalahan hubungan kekuasaan, hubungan keuangan pusat dan daerah juga menunjukkan adanya problematika yang cukup mendasar. Ketiga, otonomi daerah di Indonesia juga berhadapan dengan persoalan "desentralisasi semu" akibat logika kepartaian yang masih sangat sentralistis. Pendelegasian kewenangan dari Pusat ke Daerah dalam tubuh eksekutif ternyata tidak diikuti oleh pola pendelegasian kewenangan dalam tubuh legislatif di daerah. Keempat, regulasi politik yang ada di Indonesia belum mampu menciptakan mekanisme rekruitmen politik yang mampu melahirkan aktor yang memiliki kemampuan memadai untuk mengelola kekuasaan pemerintahan pada level lokal secara baik dan bertanggungjawab. Kelima,

${ }^{20}$ Abdul Gaffar Karim ed., Kompleksitas Persoalan Otonomi Daerah di Indonesia, Cetakan I, Jurusan Ilmu Pemerintahan UGM Kerjasama dengan Pustaka Pelajar, Yogyakarta, 2003, hlm., xviii - xxv. 
menguatnya paham "daerahisme" yang dapat dengan mudah menggiring kepada disintegrasi bangsa. Keenam, upaya untuk mereformat hubungan antar level pemerintahan tingkat lokal masih sering menemui kendala implementasi. Ketujuh, problematika hubungan antar daerah dalam membangun hubungan kerjasama antar daerah. Kedelapan, problematika hubungan eksekutif dan legislatif di daerah yang ditandai menguatnya kelembagaan eksekutif di daerah sebagai imbas semangat otonomi di satu sisi dan kelembagaan legislatif sebagai imbas pergeseran kekuasaan dari eksekutif ke legislatif di sisi yang lain. Menguatnya kelembagaan keduanya justru sering memunculkan persoalan di daerah yang disebabkan oleh kelambanan keduanya dalam merekrut sumber daya manusia yang handal. Kesembilan, otonomi daerah yang berjalan bersama dengan jatuhnya rezim politik otoriter memunculkan dua arus yang berjalan bersamaan yakni masyarakat dengan kesadaran politik yang lebih tinggi sebagai konsekuensi tersedianya ruang partisipasi melawan negara di tingkat lokal yang memperoleh penguatan tenaga akibat desentralisasi politik. Kenyataan ini memunculkan problematika dalam hal hubungan antara negara dan masyarakat di tingkat lokal. Kesepuluh, penataan institusi dan mekanisme lokal juga relatif belum matang.

Berbagai kompleksitas permasalahan tersebut serta alasan bahwa Undang-Undang Nomor 22 Tahun 1999 sudah tidak sesuai lagi dengan perkembangan zaman telah mendorong perubahan Undang-undang Nomor 22 Tahun 1999 menjadi Undang-Undang Nomor 32 Tahun 2004. Hingga kini, setidaknya telah 2 (dua) kali dilakukan perubahan terhadap Undang-undang Nomor 32 Tahun 2004 yakni: 1. Undang-Undang Nomor 8 Tahun 2005 tentang Penetapan Peraturan Pemerintah Pengganti Undang-undang Nomor 3 Tahun 2005 tentang Perubahan Atas UndangUndang Nomor 32 Tahun 2004 tentang Pemerintahan Daerah menjadi undang-undang; 2. Undang-Undang Nomor 12 Tahun 2008 tentang Perubahan Kedua Atas Undang-Undang Nomor 32 Tahun 2004 tentang Pemerintahan Daerah.

Baik oleh Undang-Undang Nomor 22 Tahun 1999 maupun dengan Undang-Undang Nomor 32 Tahun 2004 dengan segala perubahannya, pengaturan mengenai agama tidak pernah diberikan kepada daerah. Artinya, urusan atau kewenangan pengaturan sejauh menyangkut kehidupan beragama merupakan kewenangan pusat. $^{21}$

${ }^{21}$ Undang-Undang Nomor 22 Tahun 1999 menggunakan istilah “kewenangan” 
Pembatasan kewenangan daerah tersebut sudah sangat tepat dan sesuai dengan amanat konstitusi. Sebagai negara yang tidak menjadikan suatu agama tertentu sebagai dasarnya, Pasal 29 UUD 1945 yang menjamin kebebasan beragama semestinya didudukkan pada pemahaman bahwa: a. Negara tidak boleh membuat peraturan perundang-undangan atau melakukan kebijakan-kebijakan yang bertentangan dengan dasar keimanan kepada Tuhan Yang Maha Esa. Termasuk di dalamnya membuat peraturan perundang-undangan yang akan membatasi kebebasan pemeluk agama tertentu untuk melakukan ritual keagamaannya; $b$. Negara berkewajiban membuat peraturan perundangundangan atau melakukan kebijakan-kebijakan bagi pelaksanaan wujud rasa keimanan kepada Tuhan Yang Maha Esa dari segolongan pemeluk agama yang memerlukan; c. Negara berkewajiban membuat peraturan perundang-undangan yang melarang siapa pun melakukan pelecehan terhadap ajaran agama (paham ateisme). ${ }^{22}$

\section{Penutup}

Visi religius/Islami yang digulirkan di Kabupaten Tasikmalaya banyak menimbulkan pro dan kontra. Hal inilah yang menyebabkan keinginan implementasi syariat Islam secara kaffah mengalami ganjalan. Upaya yang ditempuh baik oleh pemerintah daerah maupun para tokoh agama untuk tetap mengusung syariat Islam sebagai pedoman hidup hanya dapat dilakukan melalui upaya-upaya kultural yang tidak mempunyai kekuatan yuridis.

Otonomi Daerah yang semula dimaksudkan untuk memberikan peran yang lebih bagi masyarakat di daerah dalam mengambil keputusan yang dilandasi asas demokrasi selayaknya tidak dijadikan alat legitimasi bagi pemenuhan kepentingan sesaat yang justru mengakibatkan timbulnya disintegrasi bangsa dan membuat jurang-jurang pemisah baru antar warga masyarakat dengan dikotomi antara Islam dengan non Islam atau antara Nasionalis dengan Religius. Pemerintah Daerah seharusnya lebih banyak merumuskan strategi untuk memberdayakan potensi alam dan pembangunan manusia di daerah demi kemajuan daerah.

sedangkan Undang-undang Nomor 32 Tahun 2004 menggunakan istilah "urusan". Perbedaan keduanya disinyalir oleh para pakar sebagai kemunduran konseptual.

${ }^{22}$ Hartono Mardjono, Menegakkan Syari'at Islam dalam Konteks Keiindonesian, Mizan, ctk.Pertama, Bandung, 1997, hlm. 28. 
Diskursus soal relasi agama dan negara yang selalu ditampilkan dengan kesan saling berhadapan semestinya sudah mulai ditinggalkan. Saatnya sekarang untuk menemukan strategi efektif dan konkrit bagaimana agama dapat memberikan kontribusi bagi pembangunan negara di satu pihak dan negara memberikan jaminan bagi pelaksanaan keagamaan berdasarkan jaminan akan Hak Asasi Manusia yang diatur oleh UUD 1945 di lain pihak. Beberapa muatan ajaran Islam yang telah mempengaruhi pembentukan hukum di Indonesia merupakan salah satu contohnya.

\section{Daftar Pustaka}

Abdul Gaffar Karim ed.,Kompleksitas Persoalan Otonomi Daerah di Indonesia, Cetakan I, Jurusan Ilmu Pemerintahan UGM Kerjasama dengan Pustaka Pelajar, Yogyakarta, 2003.

Haedar Nashir, Gerakan Islam Syariat: Reproduksi Salafiyah Ideologis di Indonesia, Cetakan I, Pusat Studi Agama dan Peradaban (PSAP) Muhammadiyah, Jakarta, 2007.

Hartono Mardjono, Menegakkan Syari'at Isam dalam Kontek Keiindonesian, ctk. Pertama, Bandung, Mizan,1997.

Marzuki Wahid dan Rumadi, Figh Madzhab Negara; Kritik atas Politik Hukum Islam di Indonesia, Yogyakarta, LKiS, 2001.

Republik Indonesia,Undang-undang Nomor 22 Tahun 1999 tentang Pemerintahan Daerah.

,Undang-undang Nomor 32 Tahun 2004 tentang Pemerintahan Daerah.

Peraturan Daerah Kabupaten Tasikmalaya Nomor 28 Tahun 2000 tentang Perubahan Pertama Peraturan Daerah Kabupaten Tasikmalaya Nomor 01 Tahun 2000 tentang Pemberantasan Pelacuran.

Peraturan Daerah Nomor 3 Tahun 2001 tentang Rencana Strategis Kabupaten Tasikmalaya tahun 2001-2005.

Peraturan Daerah Kabupaten Tasikmalaya Nomor 13 Tahun 2003 tentang Perubahan Kedua Peraturan Daerah Kabupaten Tasikmalaya

Nomor 03 Tahun 2001 tentang Rencana Strategis Kabupaten Tasikmalaya Tahun 2001-2005.

http://www.klikpriangan.com/102003/tajuk.htm 